\title{
Richard Ekins
}

\section{The Regulatory Responsibility Bill and the Constitution}

The Regulatory Responsibility Taskforce has recommended that Parliament enact its proposed Regulatory Responsibility Bill. The bill aims to rule out certain statutes and regulations as 'unconstitutional' by specifying principles of responsible regulation and by introducing three mechanisms certification, judicial declarations of incompatibility and interpretation - to ensure that legislation conforms to those principles. I argue that the bill itself is unconstitutional: Parliament should not enact it. Many of the principles are contentious and affirming them would distort law making and democratic politics. Authorising judges to police conformity compounds the problem. The content of the principles is likely to be settled by judicial decision, which means Parliament will face improper political pressure to do as the courts direct and the validity of much delegated legislation will be called into question.

Richard Ekins is a senior lecturer in the Faculty of Law at the University of Auckland, where he teaches legal philosophy and legislation. He works in legal and political philosophy, as well as constitutional law and theory, and much of his published work has focused on legislative authority and statutory interpretation.
The principles of responsible regulation The central clause in the taskforce's draft bill is clause 7 , entitled 'Principles'. The first sub-clause sets out 11 'principles of responsible regulation' in paragraphs (a)-(k), grouped under six subheadings. The second echoes section 5 of the New Zealand Bill of Rights Act 1990 and states that 'Any incompatibility with the principles is justified to the extent that it is reasonable and can be demonstrably justified in a free and democratic society.' It is these principles, duly limited, that are the focus of the three mechanisms.

Many of the principles are drawn from the Legislation Advisory Committee Guidelines and Cabinet Manual. The taskforce stresses the orthodoxy of the principles, saying it aimed 'to provide a simplified and streamlined set of criteria that accord with and reflect broadly accepted principles of good legislation rather than novel principles' (paragraph 1.11; the same phrase, minus the final four words, is used at paragraph 4.25). However, not all are orthodox - the taskforce has modified some of them. And many are not fit to be justiciable. I now outline the principles, noting what is heterodox and what should not be justiciable, arguing that they do not all warrant affirmation, either in their own right (as principles of good legislation) or as 'constitutional' principle.

\section{Rule of law}

The bill affirms the rule of law (paragraph (a)), but happily the taskforce has avoided one obvious trap. That is, the bill specifies four aspects of the rule of law. This is preferable to affirming 'the rule of law' in the abstract, for many vague conceptions of the ideal abound. The third aspect 
is that every person is equal before the law. The report argues that this concerns equality in the administration of law rather than substantive equality, which would preclude unjustifiable distinctions amongst persons. The report eschews this broader right to equality on the grounds that it was considered and rejected in enacting the New Zealand Bill of Rights Act. The taskforce places (far too) much weight on the Supreme Court of Canada's argument that 'equality under the law' introduces substantive equality but 'equality before the law' does not (Andrews v. Law Society of British Columbia [1989] 1

Paragraph (d) states that legislation should 'not impose, or authorise the imposition of, a tax except by or under an Act'. This is orthodox but largely redundant for ... section 22 of the Constitution Act 1986 already renders invalid any tax that is not imposed by or under an act.

SCR 143). Specifying this aspect of the rule of law is risky. It is perfectly conceivable that the courts will, either now or in ten years time, interpret the phrase to introduce substantive equality and so to require judicial assessment of the merit of any distinction made amongst classes of person.

\section{Liberties}

The bill also affirms liberty, paragraph (b) stating that legislation should:

not diminish a person's liberty, personal security, freedom of choice or action, or rights to own, use, and dispose of property, except as is necessary to provide for, or protect, any such liberty, freedom, or right of another person.

Very many legislative acts diminish a person's liberty or freedom of choice. This principle bars the imposition of duties unless those duties are necessary to protect 'any such liberty, freedom, or right of another' (the phrase omits 'personal security', although the later discussion, at paragraph 4.53, implies that this is an oversight). Imagine an act like the Bakeshop Act 1896 (New York), which prohibits any person from employing another to work in a bakery for more than 10 hours per day or 60 hours per week. That act would depart from paragraph (b), for it restricts the freedom of contract of employer (and employee), and is not necessary to protect any existing liberty or freedom of the employee (or any other person). The legislators might attempt, per clause $7(2)$, to justify their act by reference to the health of the worker or the need to protect him or her from economic exploitation. It would be open to the courts to consider this rationale and to decide that the legislation is an unjustifiable limit on liberty. This is precisely what took place in the infamous United States Supreme Court decision Lochner v. New York 198 U.S. 45 (1905). Enacting this principle opens the policy of almost every statute up to review on Lochner grounds, with that review informing interpretation and declarations (on which more below). There are very good reasons for courts not to carry out this kind of review.

\section{Taking of property}

The bill also states, in paragraph (c), that legislation should 'not take or impair ... property' unless this is necessary in the public interest and full compensation is paid, such compensation to be paid if practicable by those who benefit from the taking. This principle seems to have been the taskforce's main concern - its five examples of bad law making each concern property rights (paragraphs 2.9-2.11).

The Legislation Advisory Committee objected to Rodney Hide's original Regulatory Responsibility Bill in part because that bill purported to reflect orthodox legal principle but in truth introduced an unorthodox conception of compensation for impairment, as distinct from expropriation, of property rights. Paragraph (c) is an improvement on its precursor in the original bill, clause $6(2)(\mathrm{e})$, which proscribed taking or impairing property save for an essential public interest and on payment of full compensation. However, this paragraph is still objectionable. It conflates takings and impairment. The effect is that limiting how one uses property attracts full compensation. The taskforce argues in paragraph 4.63 that severe impairment of property rights is tantamount to a taking. This is not true, or at least not always true: banning a certain kind of dangerous vehicle from the road constitutes a severe impairment of property rights but is not a taking of those rights for communal use. In any event, the taskforce moves from its premise that severe impairment is a taking to the conclusion in the terms of clause 7 (c) that there should be 'full compensation for the taking or impairment' - no mention of severity here.

The point of the principle is to make it very expensive to limit how property owners may act, for any property owner who suffers loss from regulatory change is entitled to be made whole. Thus, if Parliament wishes to ban dangerous weapons, it must buy them. Legislation imposing mandatory closing times on certain pubs would be an impairment attracting compensation. And legislation criminalising prostitution would arguably be a taking of the goodwill of what would otherwise have been lawful brothels (the report in paragraph 4.60 takes goodwill to be property). This principle smuggles in a doctrine of regulatory takings that is foreign to our constitution. Law makers should consider the impact that legislation has on persons and their property, but this assessment is politically contentious and should not be justiciable. I note in passing that the taskforce's requirement that compensation should be paid by those who benefit from the taking is entirely novel (paragraph 4.62).

\section{Taxes and charges}

Paragraph (d) states that legislation should 'not impose, or authorise the imposition of, a tax except by or under an Act'. This 
is orthodox but largely redundant for, as the report notes at paragraph 4.67 , section 22 of the Constitution Act 1986 already renders invalid any tax that is not imposed by or under an act. Paragraph (e), which concerns charges, is less orthodox. It goes beyond the truth that charges should be limited to actual cost recovery, instead introducing the novel idea that charges should be proportionate to the benefits the payer receives. This would rule out, for example, a charge on manufacturers to meet the costs of a public inspectorate, the purpose of which is to benefit consumers. Further, this paragraph limits charges to 'the costs of efficiently providing the goods or service', which seems designed to limit actual cost recovery and to enable argument that a proposed service, function or power should be carried out by an 'efficient' (that is, lower cost) private provider.

\section{The role of the courts}

Paragraph (f) affirms the superiority of the courts in interpreting legislation. This is unremarkable but does affirm judicial supremacy in settling the scope and meaning of the principles of responsible regulation. Paragraph (g) states that if legislation authorises a minister or other public body or official to make decisions adverse to any person's right or liberty, the legislation should 'provide a right of appeal on the merits against those decisions to a court or other independent body'. This principle is novel: there is no general entitlement to an appeal on the merits in our constitution. The principle also has a very broad scope, perhaps extending to delegated law making itself, and ignores the legitimacy of decision making by ministers.

\section{Good law making}

The final four paragraphs set out the principles of 'Good law-making'. Paragraph (h) states that legislation should not be made unless there has been consultation. Contra the report, there is no general duty of consultation in our law. Further, it is extraordinary and quite contrary to the Bill of Rights 1688 that on this principle the adequacy of the parliamentary process itself is open to legal argument and judicial ruling.
The remaining three principles amount to the truism that one should not make law unless there is good reason to make law. Paragraph (i) states that legislation should not be made (or introduced to the House of Representatives) unless there has been a careful evaluation of the issue, the existing law, the public interest, the relevant options (including non-legislative options), the identity of winners and losers and foreseeable consequences. I agree. I doubt, however, that policy makers often propose and adopt legislation in any other way (although the taskforce itself violates this principle). Their analysis may be hasty or weak, but that is different.

Paragraph ( $\mathrm{j}$ ) states that legislation should produce benefits that outweigh its costs. This is unobjectionable if it is understood to be just a vague direction to consider costs. However, if policy makers and judges take it to enjoin costbenefit analysis then it is dangerous. The common good is not an aggregate capable of calculation. The injunction to weigh costs and benefits makes it likely that quantifiable outputs will loom too large in the law-making process. The report's reference to maximal net public benefit suggests as much (paragraph 4.84) and the taskforce's analysis of its own bill is not encouraging. In the final section of part 2 of its report, the taskforce purports to weigh costs and benefits. The focus is on economic benefits, weighed against actual compliance costs. This is objectionable because it ignores other reasons for good law making and non-economic objections to the proposal. Finally, paragraph $(\mathrm{k})$ states that legislation should be the most effective, efficient and proportionate response to the issue. This is close to a truism, although it may (wrongly) preclude legislation that aims to support other arrangements.

\section{The certification regime}

The central mechanism for ensuring that legislation is compatible with the principles (subject to reasonable limits per clause $7(2))$ is the certification regime. Clauses 8 and 9 require various persons to certify whether the legislation is compatible with each of the principles, and if not how it is incompatible and whether this is justified under clause $7(2)$. In respect of a government bill, the minister responsible for the bill and the chief executive of the public entity that will be responsible for administering the resulting act must certify the bill. For regulations (broadly understood), the minister responsible for the regulation, if any, and the chief executive of the public entity that will be responsible for administering it must each certify it before making it.

The chief executive does not have to state whether or why an incompatibility is justified if a minister also gives a certificate under clause 8 . The reason for this, the report states, is that the minister is the

\section{certification is at best a modest component in a careful deliberative process; much more important are time to consider the detail of proposals and an opportunity for experts, interested parties and other legislators to be heard.}

appropriate person to judge whether a departure is justified (paragraph 4.106). The taskforce concludes that in such cases the chief executive's role 'is best limited to the proposal's technical compliance with the principles set out in clause $7(1)^{\text {'. }}$ However, the final two principles require the chief executive to certify whether he or she thinks the benefits outweigh the costs and whether the legislation is the most effective, efficient and proportionate response available. This means the chief executive must in effect certify whether he or she would enact this law. The certification regime thus promises to grossly politicise chief executives and to 
arm them to veto government policy in a way that is flatly inconsistent with our constitutional arrangements.

If the minister does not certify the legislation, the chief executive will be obliged to certify it in full. The taskforce opines that this will be rare (paragraph 4.107) 'as generally the power to make legislation will be interpreted not to delegate the power to make legislation inconsistent with the principles of responsible regulation'. If my analysis above of liberty and takings is sound, then the taskforce's speculation is plainly

\section{The problems with the} certification regime are compounded by the jurisdiction to declare legislation incompatible. This jurisdiction makes what should be arguable the object of authoritative judicial ruling.

unsound. Legislation will (and should) routinely authorise delegated law makers other than ministers to depart from the principles.

It is deeply problematic to require chief executives to certify legislation. However, if one sets aside this problem, certification may seem unobjectionable: legislators should think carefully before proposing legislation. However, affirming these principles is likely to distort law making. The scheme is weighted against departures from the principles: it imposes a burden of proof on laws that limit liberty or impair property, for example. The principles are not obvious truths about what should be done. They at least require further reasoning and argument to specify them. Further, some of the principles, such as those concerning liberty, takings, charges and cost-benefit analysis, are contentious. Affirming these principles inevitably prioritises them, through salience if nothing else, over other values.

The bill demands that law makers give reasons when they depart from the principles. Legislators should give reasons for any legislative act, reasons that substantiate the claim to have made good law. More to the point, legislation should be made by way of a process that enables assertions about a proposal's justification to be tested carefully. Unsound principles are likely to distort reasoning. Even if the principles are sound, certification is at best a modest component in a careful deliberativeprocess; much moreimportant are time to consider the detail of proposals and an opportunity for experts, interested parties and other legislators to be heard.

\section{Declarations of incompatibility}

The bill introduces judicial declarations of incompatibility as a mechanism to support certification. Clause 12 authorises the superior courts to declare that legislation is incompatible with the principles specified in sections $7(1)(a)-(h)$, unless the incompatibility is justified under section $7(2)$. The power is discretionary and is subject to a temporal limit: for ten years after the commencement of this bill the courts may only issue declarations in respect of statutes that post-date it. The point of the delay is to give law makers an incentive to revise the statute book before the ten-year period expires (this incentive is reinforced by a duty on public entities, per clause 16 , to review relevant legislation). The power is modelled on section 4 of the Human Rights Act 1998 (UK), not section 3(2) as the report states. Clause 13 of the bill makes clear that a declaration of incompatibility does not render the relevant legislation invalid.

The taskforce is aware of the general reasons for courts to abstain from considering the merits of legislative choices. However, the report goes on to argue that the power to issue declarations 'is justified and necessary' to ensure compliance (paragraph 4.121). The possibility of a judicial declaration, the report suggests, is valuable primarily because it will imprint on policy makers the importance of the principles and the need to take them seriously throughout the legislative process. If those principles 'are demonstrably given careful consideration by policy-makers, the Taskforce considers that the Courts are likely to give substantial deference to the judgment of the policy-makers' (paragraph 4.122). This is speculation. The courts may well review strictly, reasoning that Parliament has charged them to police irresponsible law making.

Oddly, whilethereportgesturestowards the experience of the United Kingdom, it says only that the jurisdiction to issue declarations 'has been used in a number of significant cases, including consideration of anti-terrorism provisions' (paragraph 4.118). This lack of detailed analysis is striking, for that experience would seem highly relevant to the taskforce's proposals. The United Kingdom political authorities have repeatedly changed the law to conform to judicial declarations of incompatibility. This experience suggests that the proposed power might be very effective; however, it also suggests that the proposed power risks illegitimately prioritising judicial analysis of the merits of legislation. That is, Parliament may defer to the courts on questions that are its responsibility to answer.

The problems with the certification regime are compounded by the jurisdiction to declare legislation incompatible. This jurisdiction makes what should be arguable the object of authoritative judicial ruling. That is, the scope and meaning of the principles is settled by legal argument. The courts should not review legislation against these principles. Interestingly, the taskforce is aware of the problem. The bill excludes the final three principles (clause $7(1)(\mathrm{i})-(\mathrm{k}))$ from the scope of the jurisdiction. The reason for this is that " $\mathrm{t}$ ] he Taskforce considers that those issues are particularly unsuitable for judicial consideration, given the institutional limits of the adversarial process' (paragraph 4.124). This argument proves too much. Determining whether legislation unreasonably limits liberty or property is equally unsuitable for judicial consideration, yet the draft bill authorises just such review. The danger of the jurisdiction is that it invites the courts to review the reasonableness of all legislation. The courts lack the competence for that task and yet citizens and legislators may 
defer uncritically to their judgment about the merits of the law. The jurisdiction may also consume time and resources which the courts ought to devote to adjudicating disputes and which the parties ought to devote directly to law reform.

The jurisdiction is plainly a tool for the wealthy and organised to contest policy outside of the political process. It is also an opportunity to reopen past decisions. The point of the delay in applying the jurisdiction to legislation that predates the bill is to prompt law makers to revise the statute book to avoid declarations of incompatibility. The implication is that law makers should identify and change legislation that, for example, unreasonably impaired property without compensation. This entails that law makers should either remove the impairment (the limitation on use) or compensate. Hence, if this bill is enacted, property owners will after ten years sue for a judicial declaration that legislation that predates the bill impaired their property without compensation. In other words, the jurisdiction arms property owners to reopen and to challenge the legitimacy of past regulatory takings.

\section{The interpretive direction}

The bill introduces another supporting mechanism in clause 11, which states that '[w] herever an enactment can be given a meaning that is compatible with the principles (after taking account of section $7(2))$, that meaning is to be preferred to any other meaning.' This clause is not prominent in the scheme of the bill - it is not included in the purpose provision in clause 3 - or in the report at large. In the introduction to the report, the taskforce emphasises the jurisdiction to declare legislation incompatible (paragraphs 1.5, 1.18-1.20), but mentions the interpretive direction only in passing. That one reference, in paragraph 1.20 , is interesting for the report states that 'the existing judicial review jurisdiction would be enlivened by an interpretation provision'

In its commentary on clause 11 , the report observes that the clause is adapted from section 6 of the New Zealand Bill of Rights Act 1990. The report states that this is preferable to alternative directives such as section 8 of the (UK) Human Rights Act (the reference should be to section 3 ).
The taskforce reasons that the language they have adopted is more familiar to the New Zealand legal community and is 'less likely to result in unduly strained interpretations being given to legislation' (paragraph 4.110). The report provides no justification whatsoever for the inclusion of this clause in the draft bill, apart from the earlier reference to enlivening judicial review. The report implies that this clause is not intended to support strained interpretations. However, the courts have struggled to identify the limits of section 6 of the New Zealand Bill of Rights Act, and while the status quo ( $R \mathrm{v}$ Hansen [2007] 3 NZLR 1) may seem stable this is by no means set in stone. The British experience is not encouraging.

The clause does not apply to legislation that pre-dates the bill until ten years after its commencement. When the interpretive direction applies to legislation that postdates the bill, the courts 'will be considering a legislative text which has already been considered in terms of compatibility with those principles by' legislators and officials (paragraph 4.113). Therefore, 'this is likely to substantially reduce the prospect of interpretations being given to legislation that are contrary to the understanding of the Minister and public entities proposing the legislation'. The taskforce's concern to protect the understanding of legislators is laudable but hard to square with the generality of the principles the report affirms. This interpretive direction would pressure the courts to prefer their view of sound policy to that of Parliament.

The interpretive direction is not limited to principles (a)-(h). The courts must prefer a meaning of legislation that is consistent with all four principles of 'Good law-making', three of which the taskforce elsewhere notes are unsuitable for judicial consideration. The interpretive direction requires legal argument and judicial decision on these very issues. I expect this is an oversight. Even if the direction were limited, however, it would be very likely to undermine the clarity and stability of statute law, because the principles (subject to reasonable limits) are extremely vague. Further, as with section 6 of the New Zealand Bill of Rights Act (Drew v Attorney-General [2002] 1 NZLR 58), empowering statutes may be read to authorise only reasonable limits on liberty, or to entail compensation for impairment of property, or not to authorise any regulation that fails a costbenefit analysis. This interpretive approach will destabilise regulations as law, for they will be subject to invalidation at any time on vague grounds.

The report makes clear, at paragraphs 4.114 and 4.130 , that the point of the tenyear delay in applying clause 11 (and clause 12) to legislation that pre-dates the bill is to give legislators and their advisors sufficient time to review and update the statute book. The implication is that after ten years it is sound for the courts to adopt novel meanings that depart from the understanding and intentions of the relevant law maker. On the taskforce's understanding, clause 11 of its draft bill

\section{The bill politicises chief executives, enabling them to undermine ministers.}

constitutes a contingent amendment of all statutes that pre-date the act. The bill amends every such statute to the extent that the courts can give a novel meaning to the legislation that is consistent with the principles of responsible regulation (as the courts understand them). Parliament should not amend legislation in this reckless way.

\section{Conclusion}

The bill is hostile to our democratic constitutionalorder.Many of the principles it affirms are heterodox and should not be justiciable. The principles jointly form a vague and distorted code for law making, which judges will have authority to interpret and to specify. The bill politicises chief executives, enabling them to undermine ministers. It also authorises courts to review the detail of policy, illegitimately constraining Parliament and calling into question the validity of delegated legislation. Parliament should not disrupt the constitution by enacting this bill. 